from "filled" milks by babies one week old. Lancet, $i i$ : 1099 (1965).

24. Widdowson, E. M., Dauncey, J., and Shaw, J. C. L.: Trace elements in fetal and early postnatal development. Proc. Nutr. Soc., 33: 275 (1974).

25. Widdowson, E. M., and Dickerson, J. W. T.: In: C. L. Comar and F. Bronner: Mineral Metabolism. Vol. II, Part A (Academic Press, New York 1961).

26. Wilson, J. F., and Lahey, M. E.: Failure to induce dietary deficiency of copper in premature infants. Pediatrics, 25: 40 (1960).

27. Dow Corning Corporation, Medical Products, Midland, Mich.

28. Lewis Woolf Griptight Ltd., Selly Oak, Birmingham, England.

29. Perkin Elmer, atomic absorption spectrophotometer, model 306.

30. Portex Ltd., Hythe, Kent, England.

31. Pye Unicam, atomic absorption spectrophotometer, model S.P.90.

32. We are grateful to all the nurses who took such care with the balances and to

Copyright (C) 1977 International Pediatric Research Foundation, Inc.
Calvin Davies for his accurate work in the laboratory.

33. The work presented here was supported by a grant from the Medical Research Council, England.

34. The present address of Dr. M. J. Dauncey is: Medical Research Council Dunn Calorimetry Group, Institute of Animal Physiology, Babraham, Cambs.

35. Dr. J. Urman is a British Council scholar. Present address: Department of Paediatrics, Htal. Mat. Inf. R. Sarda, Luca 2151, Buenos Aires, Argentina.

36. Requests for reprints should be addressed to: J. C. L. Shaw, M.D., Department of Paediatrics, University College Hospital, Gower St., London, W.C.1. (England)

37. Received for publication October 22, 1976.

38. Accepted for publication February 15, 1977.
Carbonic anhydrase red blood cell renal tubular acidosis

\title{
Red Blood Cell Carbonic Anhydrase Activity in Children with Distal Renal Tubular Acidosis
}

\author{
B. S. KAPLAN, ${ }^{(17)}$ M. MILLS, P. HECHTMAN, AND D. LEBLANC
}

Departments of Nephrology and Biochemical Genetics, McGill University-Montreal Children's Hospital Research Institute, and Medical Research Council of Canada Human Genetics Group, Montreal, Quebec, Canada

\section{Summary}

Red blood cell carbonic anhydrase activity was studied in three children with distal renal tubular acidosis, the parents of one of these patients, and in control subjects. Although each patient had distal renal tubular acidosis as defined by an inappropriately high urine $\mathrm{pH}$ in the face of a systemic metabolic acidosis, hyperchloremia and a low (U-B)pCO $\mathrm{O}_{2}$, they differed in that two had deafness. The deafness was inherited as an autosomal recessive mode in one and by an autosomal dominant gene in the other.

Red blood cell carbonic anhydrase activity was determined in hemoglobin-free hemolysate by the esterolytic action of the enzyme on the substrate $p$-nitrophenyl acetate. The two isoenzymes, $B$ and $C$, of carbonic anhydrase were identified using polyacrylamide disc gel electrophoresis. The red blood cell carbonic anhydrase activity of nine control children aged 2-10 years was $3.8(3.2-5.0)$ units/g $\mathrm{Hb}$. The values obtained from the three patients were $3.0,3.7$, and 4.36 units $/ g$ Hb. These did not differ from those of the control subjects. No abnormalities were found in the ratios of the $B$ and $C$ peaks or in their electrophoretic mobility.

\section{Speculation}

Although carbonic anhydrase appears to have an important role in the acidification of the urine, and although an abnormality in red blood cell carbonic anhydrase has been described in a patient with renal tubular acidosis and deafness, no abnormalities could be defined in red blood cell carbonic anhydrase activity in our three patients with renal tubular acidosis, two of whom were deaf.

Patients with renal tubular acidosis (RTA) have reduced hydrogen ion secretion or bicarbonate reclamation which results in hyperchloremic metabolic acidosis and an inappropriately alkaline urine $\mathrm{pH}$. Although the pathogenesis of RTA is incompletely understood, two main forms of RTA have been defined (10): distal RTA (type I), in which there is reduced secretion of hydrogen ions into the urine, and proximal RTA (type II), in which there is incomplete reclamation of filtered bicarbonate by the proximal tubule.

Carbonic anhydrase (CA) is an enzyme which has a role in the regulation of the acid-base status of the body. There appear to be two major isoenzymes of CA (12): C (high activity) and B (low activity). CA can be demonstrated in two main sites in the nephron: in the proximal and distal tubular cells themselves and in the brush border of the proximal tubular cells (11). Shapira et al. (14) found abnormal red blood cell CA activity in three members of a kindred with RTA and deafness. This abnormality was described as an inactive mutant form of CA B. Since there does not appear to be tissue specificity for CA (6), these workers postulated a similar defect in the renal tubular cells of their patients. Although this could be an important observation about the pathogenesis of RTA, these findings have not been verified.

We have studied red blood cell CA activity in three children with RTA, two of whom were deaf, but were unable to demonstrate any abnormality in the red blood cell CA isoenzymes.

\section{MATERIALS AND METHODS}

\section{CA ACTIVITY OF HEMOGLOBIN-FREE HEMOLYSATE (HFH)}

HFH was prepared from heparinized fresh blood after determination of the hematocrit (14). Red blood cell CA activity is present in both the raw hemolysate and in the HFH. The latter is used as the CA activity is not stable in the raw hemolysate. Unfortunately, it was not possible to remove all the hemoglobin from the $\mathrm{HFH}$ and this accounted for the presence of small amounts of residual hemoglobin. CA activity of reconstituted 
lyophilized HFH was measured by the esterolytic activity of CA on $p$-nitrophenyl acetate (PNPA) (Sigma Chemical Co., St. Louis, Mo.) (14). This substrate produces a chromogen, $p$ nitrophenol (PNP), when hydrolyzed. Although the absorption maximum of PNP occurs at $405 \mathrm{~nm}$, the wavelength $348 \mathrm{~nm}$ (Unicam II spectrophotometer, Canadian Laboratory Supplies, Montreal, Canada) was used to monitor the reaction in order to reduce absorbance from residual hemoglobin in the HFH. The molar extinction coefficient of PNP at $348 \mathrm{~nm}$ was determined as $5400 \mathrm{~cm}^{-1}$ using a standard solution of PNP. A fresh $0.003 \mathrm{M}$ solution of PNPA was prepared for each analysis.

A unit of CA activity is defined as that amount of enzyme which catalyzes the formation of $1 \mu \mathrm{mol} \mathrm{PNP} / \mathrm{min}$ under standard conditions of incubation. Incubation mixtures contained $0.03 \mathrm{M} \mathrm{NaPO}_{4}(\mathrm{pH} \mathrm{7.4)}$, PNPA $1 \mathrm{mM}$, and varying amounts of $\mathrm{HFH}$ in a total volume of $3.0 \mathrm{ml}$. The reaction was initiated by the addition of PNPA. A blank without the enzyme was used as a control for spontaneous hydrolysis of the substrate. The mixture was incubated for $20 \mathrm{~min}$ at room temperature. The rate of hydrolysis was linear with time between 2 and 20 min (Fig. 1). The reaction was also linear with concentrations of HFH between 1 and $20 \mu l$.

Specific activities are reported as units/g hemoglobin (units/g $\mathrm{Hb}$ ). In order to relate the enzyme activity of the $\mathrm{HFH}$ to the hemoglobin concentration in the original blood sample, the hematocrit value was divided by 3 and expressed as grams of hemoglobin $/ \mathrm{ml}$ blood. Lyophilized $\mathrm{HFH}$ was reconstituted to one-fifth of the volume of the raw hemolysate used in its preparation. Using these two procedures, an empiric formula incorporating the extinction coefficient could be calculated: units $\mathrm{CA} / \mathrm{g}$ hemoglobin $=\mathrm{OD} / \mathrm{min} / \mu \mathrm{l} \mathrm{HFH} \times 667$.

\section{ELECTROPHORESIS}

Electrophoresis of HFH was carried out by polyacrylamide disc gel electrophoresis (3). CA activity in the gel was quantitated by eluting $1.7-\mathrm{mm}$ cross-sectional slices in $200 \mu \mathrm{l}$ buffer at $4^{\circ}$ overnight. Since recovery of enzyme activity was variable the results could only be interpreted qualitatively. The volume of running gel was $1.2 \mathrm{ml}$ and that of spacer gel, $0.1 \mathrm{ml}$. A $50-\mu \mathrm{l}$ sample of HFH with at least 0.2 units $(\mu \mathrm{M} / \mathrm{min})$ of CA activity/ $\mathrm{ml} \mathrm{HFH}$ was applied to the gel together with $2-4$ sucrose crystals and 2-5 $\mu$ l bromphenol blue tracking dye. Parallel samples were electrophoresed to compare protein bands stained with amido black to areas containing enzyme activity (Fig. 2). Electrophoresis was done using a constant amperage ( $4 \mathrm{ma} / \mathrm{gel}$ ) with a voltage limit of $300 \mathrm{~V}$. Electrophoresis was continued for 1.5 times the time taken for the tracking dye to reach the end of the gel $(1.5 \times$ $80 \mathrm{~min}$ ). Under these conditions residual hemoglobin in the sample served as an internal tracking dye. The slices of gel were

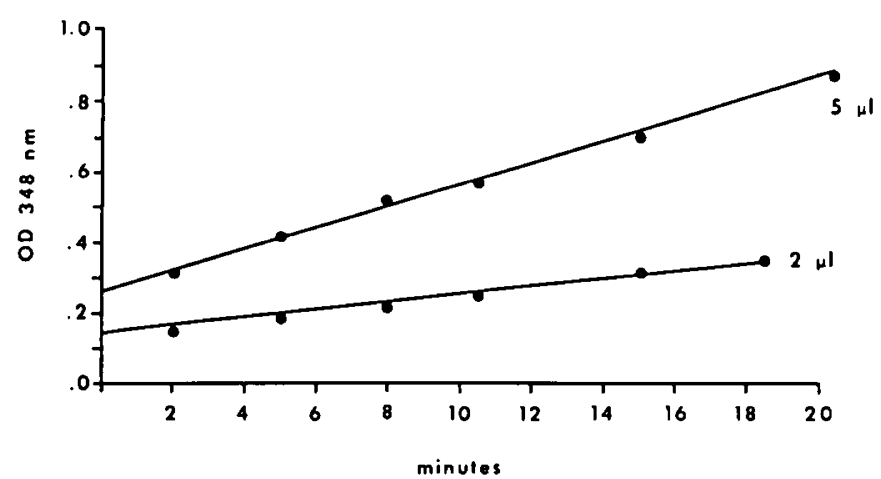

Fig. 1. Activity of red blood cell carbonic anhydrase hemoglobin-free hemolysate in volumes of $2 \mu \mathrm{l}$ and $5 \mu \mathrm{l}$ with times ranging from 2-20 min. Linear relationships were obtained with both concentrations at $O D$ $348 \mathrm{~nm}$ between 2 and $20 \mathrm{~min}$.

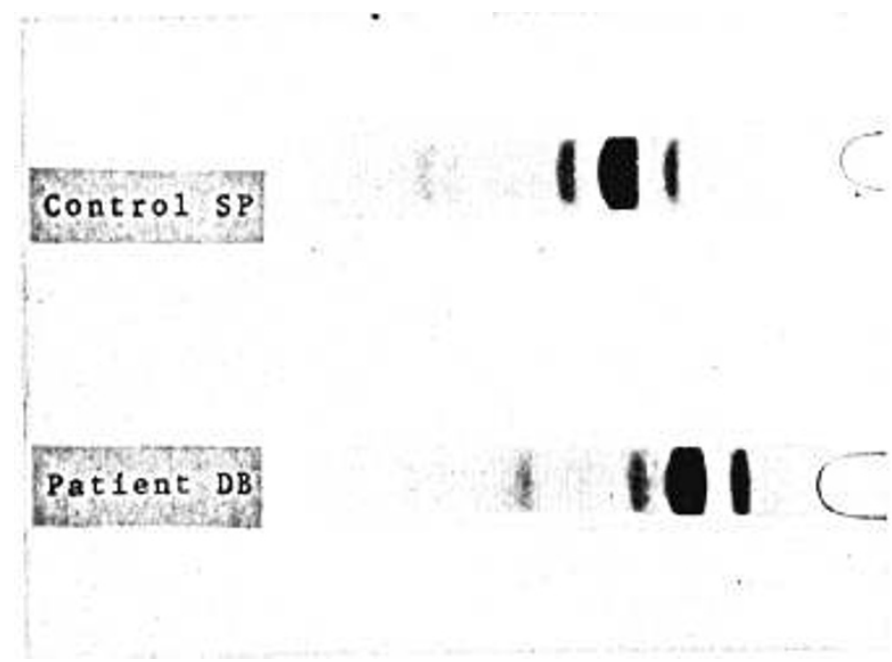

Fig. 2. Polyacrylamide gels stained with amido black from a control patient and patient DB. The heavy band represents residual hemoglobin which serves as an internal tracking dye.

obtained by cross-sectional slicing of the gel using a device with a series of razor blades alternating with metal washers and mounted on two metal bolts to provide sections of $1.7 \mathrm{~mm}$ thickness. Each slice was placed in a small tube containing 200 $\mu$ l buffer and was kept overnight at $4^{\circ}$ to elute the enzyme. Each eluant $(200 \mu \mathrm{l})$ was added to buffer $(1.0 \mathrm{ml})$, substrate $(1 \mathrm{ml})$, and water $(800 \mu \mathrm{l})$, and allowed to remain at room temperature for $20 \mathrm{~min}$ after which the $O D$ at $348 \mathrm{~nm}$ was recorded. A blank without eluant was used.

The ethical aspects of this study were approved by the Committee on Medical and Dental Evaluation of the Montreal Children's Hospital and informed consent was obtained.

\section{PATIENTS}

Clinical and laboratory features of three children with RTA are shown in Table 1. Each was diagnosed as having distal RTA for the following reasons: a hyperchloremic metabolic acidosis; an inappropriately alkaline urine $\mathrm{pH}$ (above 6.0) in the face of a very low serum bicarbonate concentration (less than $13 \mathrm{mEq} /$ liter); (U-B) $\mathrm{pCO}_{2}$ less than $12 \mathrm{~mm} \mathrm{Hg}(7,8)$; maintenance of normal acid-base balance and growth with sodium bicarbonate therapy of 1-3 mEq/ $\mathrm{kg} / \mathrm{day}$; radiologic evidence of nephrocalcinosis (in DB and DR).

$\mathrm{CA}$ activity was measured in $\mathrm{HFH}$ from control subjects and from the parents of DB. The CA activity of their HFH was also studied by polyacrylamide gel electrophoresis.

\section{RESULTS}

The red blood cell CA activity of nine control subjects aged 210 years was $3.8(3.2-5.0)$ units/g Hb. The values of one of these repeated on two occasions from different samples of blood were 4.0 and 3.9 units/g $\mathrm{Hb}$. CA activity of seven adult control subjects was $4.8(3.2-6.4)$ units/g Hb. Determinations were repeated on two separate occasions on freshly prepared samples from three adult control subjects and were 6.4 and 5.7, 4.8, and 4.9 , and 4.7 and 5.6 units/g $\mathrm{Hb}$, respectively.

The results of CA activity of HFH of the three children with RTA did not differ markedly from those of the control subjects: DB 3.0, DR 3.7, and BN 4.36 units/g Hb. Similarly, the mother and father of DB had values of 3.79 and 5.50 units/g Hb. There was a similar increment in CA activity of a patient and control subject when the assay was done at $20^{\circ}$ and $37^{\circ}$. The CA activity of $\mathrm{BN}$ was 3.8 units/g $\mathrm{Hb}$ at $20^{\circ}$ and 5.9 units $/ \mathrm{g} \mathrm{Hb}$ at $37^{\circ}$, and the control sibject's values were 3.5 units/g Hb and 8.1 units/g $\mathrm{Hb}$ at $20^{\circ}$ and $37^{\circ}$. 
CARBONIC ANHYDRASE IN RENAL TUBULAR ACIDOSIS

Table 1. Clinical and laboratory features of three patients with renal tubular acidosis

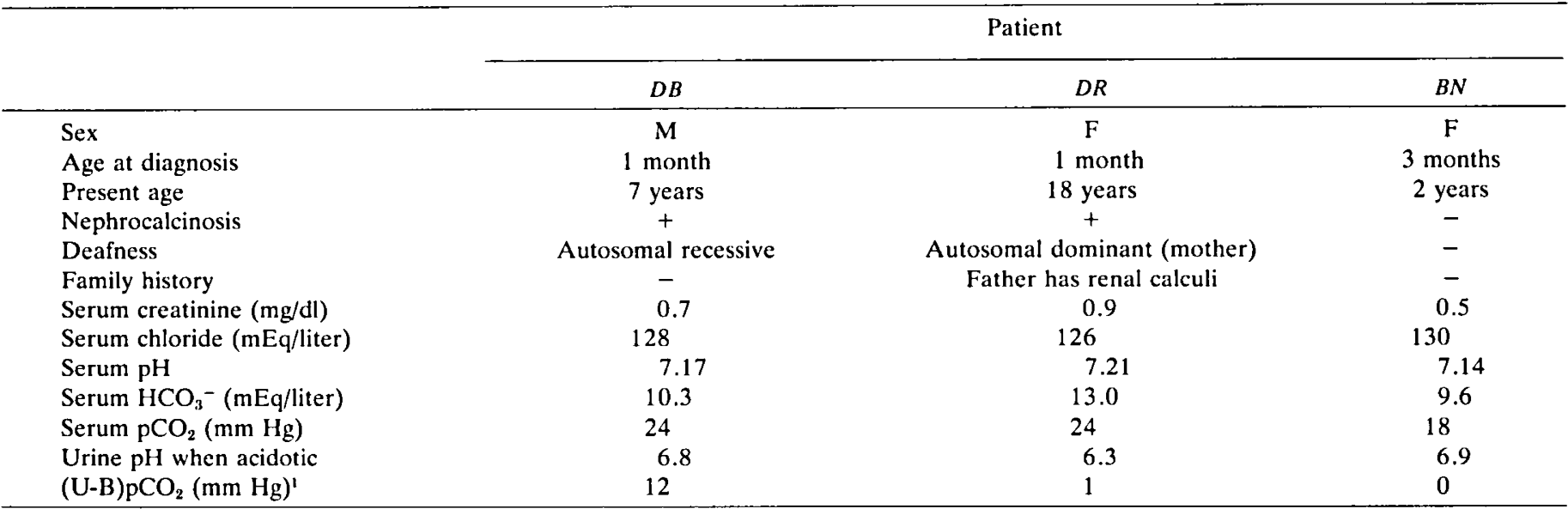

' After loading with $\mathrm{NaHCO}_{3}$, urine $\mathrm{pH}>7.2$.

Polyacrylamide gel electrophoresis resolves the HFH CA activity into two peaks. The relative concentration of enzymes in these peaks can be estimated by integration. The fast moving peak was designated $\mathrm{CA} \mathrm{C}$ and the slower moving peak, CA B (12). The results of electrophoresis of $\mathrm{HFH}$ from a normal adult are shown in Figure 3.

Electrophoretic studies did not reveal an abnormal ratio of CA $\mathrm{B}$ to $\mathrm{CA} \mathrm{C}$ in the patients when compared to control subjects. The ratio of the $B$ to $C$ peak in control subjects was $0.45-0.49$. The ratio in the patients was DB 0.48 , DR 0.27 , and $B N 0.42$. In Figure 4 the electrophoretic patterns of CA B and C activity of patient DB and his parents are shown. Please note that the $B$ and $C$ peaks do not differ from those of the control subject shown in Figure 3. Furthermore, there were no differences in electrophoretic mobility.

\section{DISCUSSION}

CA catalyzes the hydration of carbon dioxide and the dehydration of bicarbonate ions (2) and has been demonstrated in red blood cells, kidney, the gastrointestinal tract, and other tissues of the body. Two major isoenzymes of CA have been identified in red blood cells and have been designated $C A B$ and $C A C$. Although CA C is widely distributed, the B isoenzyme appears to be limited to the medulla of the kidney and the gall bladder mucosa (6).

Since CA C isolated from dog kidney resembles dog red blood cell CA C (6), this had led to speculation that a deficiency or absence of renal CA activity could be reflected in a similar change in the red blood cell. Therefore, Shapira et al. (14) studied red blood cell CA activity in a patient with RTA and deafness. They found reduced activity of CA B and defined this as an inactive mutant form of $\mathrm{CA} B$. Evidence implicating an abnormality of CA in the pathogenesis of proximal RTA has been provided by Donckerwolcke et al. (5), who found no inhibition of CA after acetazolamide administration to an infant with proximal RTA. The conclusion from this study was that if CA were active, administration of acetazolamide should have increased the patient's acidosis.

We reasoned that if the finding of Shapira et al. (14) could be confirmed in additional patients with RTA, this might be important in providing further understanding about the pathogenesis of RTA. Although our three patients have distal RTA they are not identical to the case of Shapira et al., case who has been defined as an example of type III RTA (13). Patients with Type III RTA have distal RTA but in addition exhibit marked wasting of bicarbonate (13).

RTA associated with nerve deafness has been described in a number of reports and may represent another genetic variant of

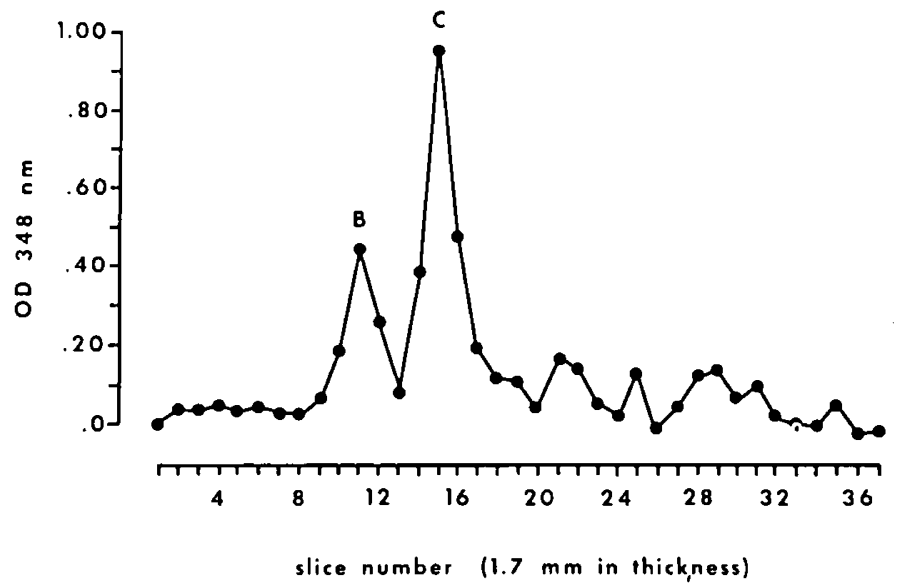

Fig. 3. Electrophoresis of red blood cell carbonic anhydrase hemoglobin-free hemolysate by polyacrylamide gel electrophoresis from a normal adult. Two peaks, designated B and C, are shown. The cathode is on the right.
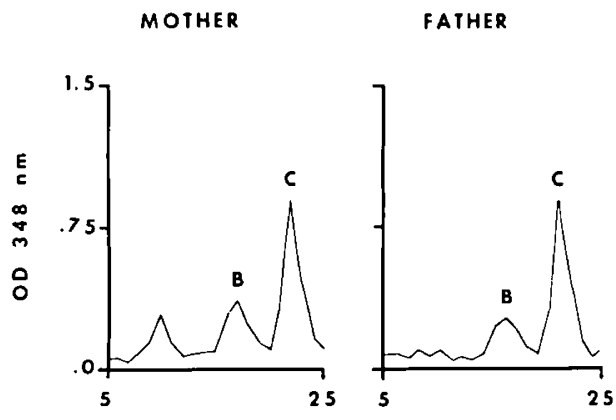

PROBAND

slice number

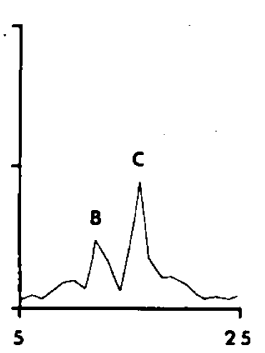

Fig. 4. Electrophoretic patterns of red blood cell carbonic anhydrase in hemoglobin-free hemolysate. Carbonic anhydrase (CA) activity of isoenzymes $B$ and $C$ of patient $D B$ and his parents are shown. Each slice is $1.7 \mathrm{~mm}$ thick. The mother has an additional peak designated $\mathrm{A}$; this may represent degradation of $\mathrm{CA} \mathrm{B}$ and/or $\mathrm{C}$.

distal RTA (4). Thus, primary distal RTA may be inherited as an autosomal dominant gene, as an autosomal recessive gene, in association with several genetically transmitted syndromes, or in association with nerve deafness (4). Patient DB appears to be another case of distal RTA and nerve deafness; DR may have an 
autosomal recessive form of RTA, but had strong vertical family history of deafness; the third child had normal hearing.

No abnormalities in total CA activity, isoenzyme distribution, or in electrophoretic mobility could be demonstrated in our three patients with RTA. This may be due to differences in methodology, genetic heterogeneity, or the appearance of the two findings may have been fortuitous. Although we used a different method for demonstrating $\mathrm{CA} B$ activity, no abnormality of CA B could be shown.

The finding of almost complete absence of CA B in the red blood cells of patients with thyrotoxicosis (15) and the demonstration that $\mathrm{CA}$ in rat renal cortex can be inhibited by parathyroid hormone (1) is further evidence that many different factors can influence $\mathrm{CA}$ activity. Therefore, a reduction in CA B activity in the red blood cells of a patient with RTA may not be the cause of the RTA but may be related to other factors, for example, secondary hyperparathyroidism which occurs in some patients with RTA (9).

\section{CONCLUSION}

Red blood cell carbonic anhydrase activity and the two isoenzymes, B and C, of carbonic anhydrase were normal in three children with distal renal tubular acidosis; two of these patients were deaf. Therefore, although defective red blood cell carbonic anhydrase B activity has been demonstrated previously in a child with renal tubular acidosis and deafness, this finding cannot be demonstrated in every patient with these two associated abnormalities.

\section{REFERENCES AND NOTES}

1. Beck, N., Kim, K. S., Wolak, M., Davis, B. B., and Donald, D. H.: Inhibition of carbonic anhydrase by parathyroid hormone and cyclic AMP in rat renal cortex in vitro. J. Clin. Invest., 55: 149 (1975).

2. Carter, M. J.: Carbonic anhydrase: Isoenzymes, properties, distribution, and functional significance. Biol. Rev., 47: 465 (1972).
3. Davis, B. J.: Disc electrophoresis. II. Methods and application to human serum proteins. Ann. N. Y. Acad. Sci., 121: 404 (1966).

4. Donckerwolcke, R. A., van Biervliet, J. P., Koorevaar, G., Kuitjen, R. H., and van Stekelenburg, G. J.: The syndrome of renal tubular acidosis with nerve deafness. Acta Paediat. Scand., 65: 100 (1976).

5. Donckerwolcke, R. A., van Stekelenburg, G. J., and Tiddens, H. A.: A case of bicarbonate-losing renal tubular acidosis with defective carbonanhydrase activity. Arch. Dis. Childhood, 45: 769 (1970).

6. Funakoshi, S., and Deutsch, H. F.: Human carbonic anhydrases. VI. Levels of isoenzymes in old and young erythrocytes and in various tissues. J. Biol. Chem., 246: 1088 (1971).

7. Halperin, M. L., Goldstein, M. B., Haig, A., Johnson, M. D., and Stinebaugh, B. J.: Studies on the pathogenesis of Type I (distal) renal tubular acidosis as revealed by the urinary $\mathrm{pCO}_{2}$ tensions. J. Clin. Invest., 53: 669 (1974).

8. Hutcheon, R. A., Kaplan, B. S., and Drummo.ıd, K. N.: Distal renal tubular acidosis in children with chronic hydronephrosis. J. Pediat., 89: 372 (1976).

9. Michelis, M. F., Drash, A. L., Linarelli, L. G., De Rubertis, R. F., and Davis, B. B.: Decreased bicarbonate threshold and renal magnesium wasting in a sibship with distal renal tubular acidosis (Evaluation of the pathophysiologic role of parathyroid hormone). Metabolism, 21: 905 (1972).

10. Morris, R. C.: Renal tubular acidosis: Mechanism, classification, implications. N. Engl. J. Med., 281: 1405 (1969).

11. Rector, F. C., Carter, N. W., and Seldin, D. W.: The mechanism of bicarbonate reabsorption in the proximal and distal tubule of the kidney. J. Clin. Invest., 44: 278 (1965)

12. Rickli, E. E., Gazanfer, S. A. S., Gibbons, B. H., and Edsall, J. T.: Carbonic anhydrases from human erythrocytes. J. Biol. Chem., 239: 1065 (1964)

13. Sebastian, A., McSherry, E., and Morris, R. C.: Metabolic acidosis with special reference to the renal acidosis. In: B. M. Brenner and F. C. Rector: The Kidney, pp. 615-660 (W. B. Saunders Co., Philadelphia, 1976).

14. Shapira, E., Ben Yoseph, Y., Eyal, F. G., and Russel, A.: Enzymatically inactive red cell carbonic anhydrase $B$ in a family with renal tubular acidosis. J. Clin. Invest., 53: 59 (1974).

15. Weatherall, D. J., and McIntyre, P. A.: Developmental and acquired variations in erythrocyte carbonic anhydrase isozymes. Brit. J. Haematol., 13: 106 (1967).

16. This research was supported by the Medical Research Council of Canada Grant MA-1579 and a grant from the RVH-MCH Chapter Kidney Foundation of Canada.

17. Requests for reprints should be addressed to: B. S. Kaplan, M.D., Department of Nephrology, Montreal Children's Hospital, 2300 Tupper St., Montreal, Quebec (Canada).

18. Received for publication December 9,1976

19. Accepted for publication March 2, 1977.

\title{
Prednisone Effects on Postnatal Brain Development of Rats Following Maternal Therapy
}

\author{
MARTA C. ROMANO, ${ }^{(23)}$ INÉS A. GIOIA, AND M. VIRGINIA BERNASCONI \\ Instituto de Fisiología, Facultad de Ciencias Médicas, Universidad Nacional de Rosario, Argentina
}

\section{Summary}

16- $\beta$-Metilprednisone was administered in the last week of pregnancy in order to study its effects on postnatal brain development of the litters. Two groups of pregnant inbred rats were used for the experiments. Group I received $1.25 \mathrm{mg} / \mathrm{kg} /$ day 16 $\beta$-metilprednisone. Group II served as untreated controls. The litters were killed either within $24 \mathrm{hr}$ after birth, at 17 days, or at 45 days of age. Treated litters (animals whose mothers received the steroid) had a decreased body weight at 17 days of age. Wet brain weight was decreased in the same group. At 17 and 45 days of life treated rats showed a dry brain weight lower than that of controls. Newborn and 17-day-old rats whose mothers received the steroid showed a decreased content of brain proteins. Total lipids, cholesterol, and phospholipids were reduced in the brain of treated rats at $\mathbf{4 5}$ days of life. Brain phospholipids were also decreased in 17-day-old rats. These results show that 16- $\beta$-metilprednisone administration to pregnant rats produces long lasting changes in brain chemical composition.

\section{Speculation}

The brain lipid deficiencies observed may interfere with the myelination process. Further studies are needed to test whether 